\title{
The role of inflammatory reaction in chronic venous disease of the lower limb
}

\author{
Ketan Vagholkar*, Shivangi Garima, Yash Kripalani
}

Department of Surgery, D.Y. Patil University School of Medicine, Navi Mumbai, Maharashtra, India

Received: 27 March 2019

Revised: 12 April 2019

Accepted: 13 April 2019

\author{
*Correspondence: \\ Dr. Ketan Vagholkar, \\ E-mail: kvagholkar@yahoo.com
}

Copyright: () the author(s), publisher and licensee Medip Academy. This is an open-access article distributed under the terms of the Creative Commons Attribution Non-Commercial License, which permits unrestricted non-commercial use, distribution, and reproduction in any medium, provided the original work is properly cited.

\begin{abstract}
Chronic venous disease is the problem which is assuming alarming proportions in subjects whose occupation involves prolonged sitting or standing. The exact mechanism by which the venous system gets damaged continues to be a subject of endless research. The role of inflammation is a significant factor in the evolution of chronic venous disease. Awareness of this mechanism can help in both prevention and treatment of this complex vascular disorder. The paper reviews inflammatory mechanism underlying the pathogenesis of chronic venous disease in lower limbs.
\end{abstract}

Keywords: Chronic, Venous, Disease, Inflammation, Leukocytes

\section{INTRODUCTION}

Chronic venous disease (CVD) is an insufficiency of the peripheral veins caused by either partial or total obstruction, endothelial distention or alteration of routine venous function. ${ }^{1-3}$ The disease traditionally was more prevalant in individuals who were involved in an occupation involving prolonged standing. However, the disease now affects even those individuals whose occupation involves prolonged hours of sitting. CVD if left untreated can lead to a multitude of complications which at times can even be lethal as in deep vein thrombosis. A large number of articles have been published which postulate various hypothesis for etiopathogenesis of CVD. ${ }^{3-7}$ Significant number of articles stress on inflammatory reaction underlying CVD affecting the lower limbs. ${ }^{8-9}$

\section{FEATURES OF CVD}

Chronic venous disease of lower limb can present in a variety of ways. The symptoms are subtle to start with but may progress rapidly eventually leading to severe incapacitation. This may interfere with daily functioning of these individuals. These features include telangiectasis, pedal edema, varicosities, pigmentary changes and chronic leg ulceration. ${ }^{10-12}$ Chronic venous insufficiency (CVI) is a combination of edema, skin changes and ulceration. Various classifications have been proposed. However the CEAP classification created by the American venous forum is the one widely used. This classification officially recognized CVD and thereby helping in managing such cases at a very early stage. ${ }^{3}$

\section{PATHOPHYSIOLOGY}

The clinical features seen in CVD are an end result of venous hypertension. ${ }^{13,14}$ Venous wall abnormalities including valvular incompetence constitutes the basis of CVD. Significant pathological changes occur in the venous wall which lead to functional damage. ${ }^{15-17}$ The damage is in both the wall as well as the valve. This leads to reversal of flow or reflux which is seen at all levels that is superficial vein, perforator, and deep veins. The smooth muscle and connective tissue fibers which are abundantly found in tunica media, are the first to get 
affected. ${ }^{18-20}$ There is significant alteration in composition of intracellular matrix. It is the composition of the intracellular matrix that is responsible for maintaining integrity of venous wall. The intracellular matrix is predominantly glycosaminoglycans. $^{21,22}$ It's interaction with smooth muscles and elastic fibers is responsible for the venous wall to endure high pressures. Even collagen and elastin in venous wall adds to the resilient and endurance of the venous wall. ${ }^{23,24}$

In CVD patients there is alteration of elastic fibers which gets separated from smooth muscle fibers. ${ }^{25,26}$ There may be a deficiency of various types of collagen in such patients (especially type III). ${ }^{27,28}$ Various enzymes may be released by stagnant inflammatory cells thereby contributing to CVD. Release of matrix metalloproteinase (MMP) followed by its activation can cause dissolution of collagen in intracellular matrix. ${ }^{29,30}$ This leads to significant weakening of the venous wall. Furthermore, activation of endocrinal cells releases Beta transforming growth factor (B-TGF) which causes migration of muscularis cells with accompanying proliferation in intimal layers. $^{24,27}$

The long-lasting secretion of B-TGF induces both MMP and tissue inhibitor of metalloproteinase (TIMP) release. This alteration of balance between MMP and TIMP leads eventually to significant damage of extracellular matrix. ${ }^{28}$

In addition to this superimposed but altered blood flow pattern and hemodynamics add to valvular damage. Persistent reflux leads to extension of valvules, atrophy of cusps and hemodynamic alteration. All the aforementioned factors perpetuate the process of chronic inflammation. $^{31}$

Several cellular events contribute in a large way to the inflammatory process. ${ }^{31}$ Extensive leucocyte infiltration mainly macrophages and lymphocytes are seen in CVD patients. Other cells which are found to increase are granulocytes, monocytes, macrophages and lymphocytes. ${ }^{32}$ Continuous high intravascular pressure leads to increase in sheering stress and perpetuates increased endothelial cells and leucocyte activation. ${ }^{33}$ Lymphocytes adhere to the endothelial cells, leading to a series of effects such as endothelial cell constriction, selectin expression, release of Von Willebrand factor, cytokines, adhesion molecules and tissue factors. ${ }^{33}$

Extravasation of leucocytes takes place in stepwise manner. Initially leucocytes stick to endothelial wall by selectin molecules which eventually tethers leucocytes to endothelial cells. This leads to further activation of leucocytes there by compounding the inflammatory process. ${ }^{31,33}$ Besides leucocytes, RBCs also extravasate due to venous hypertension. The degradation products of RBCs are potent chemo attractants and are presumed to serve as the initial signal for leucocytes. Hypoxia which is a common accompaniment can lead to increased production of platelet aggravating factor (PAF). ${ }^{34}$ PAF in turn further activates leucocytes. Plasma levels of selectin are very high in CVD patients. Besides selectin, a variety of other molecules are quite high in CVD patients. These add symbiotically in bringing about a conformational change in basic structure of integrin molecules.

Leucocyte sequestration due to stasis in valve cusps add to the damage caused to the venous wall. ${ }^{30}$ As per white cell trapping hypothesis there is massive leucocyte activation in micro-circulation followed by their migration into the subcutaneous tissue. These activated leucocytes release cytotoxic molecules which are instrumental in causing extensive damage of valve cusps and venous wall eventually leading to breakdown of the skin. $^{31,33,35}$

\section{CONCLUSION}

Of the various theories proposed, leucocyte activation theory is the most commonly accepted theory to explain the sequelae seen in CVD. Targetted therapy towards control of the inflammatory process may perhaps help in preventing disastrous complications of CVD.

\section{Funding: No funding sources \\ Conflict of interest: None declared \\ Ethical approval: Not required}

\section{REFERENCES}

1. Beaglehole R. Epidemiology of varicose veins. World J Surg. 1986;10:898-902.

2. Callam WA, West A. Epidemiology of varicose veins. Br J Surg. 1994;81:167-73.

3. Eklöf B, Rutherford RB, Bergan JJ, Carpentier PH, Gloviczki P, Kistner RL, et al. Revision of the CEAP classification for chronic venous disorders: consensus Statement. J Vasc Surg. 2004;40:124852.

4. Ono T, Bergan JJ, Schmid-Schönbein GN, Takase S. Monocyte infiltration into venous valves. J Vasc Surg. 1998;27:158-166.

5. Arnoldi CC. Venous pressure in patients with valvular incompetence of the veins of the lower limb. Acta Chir Scand. 1966;132:427-30.

6. Travers JP, Brookes CE, Evans J, Baker DM, Kent C, Makin GS, Mayhew TM. Assessment of wall structure and composition of varicose vein with reference to collagen, elastin and smooth muscle content. Eur J Vasc Endovasc Surg. 1996;11:230-7.

7. Kockx MM, Knaapen MW, Bortier HE, Cromheeke KM, Boutherin-Falson O, Finet M. Vascular remodeling in varicose veins. Angiology. 1998;49:871-7.

8. Porto LC, da Silveira PR, de Carvalho JJ, Panico MD. Connective tissue accumulation in the muscle layer in normal and varicose saphenous veins. Angiology. 1995;46:243-9.

9. Svejcar J, Prerovsky I, Linhart J, Kruml J, Beckova B. Content of collagen, elastin, and hexosamine in primary varicose veins. Clin Sci. 1963;24:325-30. 
10. Jacob MP, Badier-Commander C, Fontaine V, Benazzoug Y, Feldman L, Michel JB. Extracellular matrix remodeling in the vascular wall. Pathol Biol. 2001;49:326-32.

11. Porto LC, Azizi MA, Pelajo-Machado M, Matos da SP, Lenzi HL. Elastic fibers in saphenous varicose veins. Angiology. 2002;53:131-40.

12. Woodside KJ, Hu M, Burke A, Murakami M, Pounds LL, Killewich LA, et al. Morphologic characteristics of varicose veins: possible role of metalloproteinases. J Vasc Surg. 2003;38:162-9.

13. Sansilvestri-Morel P, Rupin A, Jaisson S. Synthesis of collagen is dysregulated in cultured fibroblasts derived from skin of subjects with varicose veins as it is in venous smooth muscle cells. Circulation. 2002;106:479-83.

14. Nicolaides AN. Chronic venous disease and the leukocyte endothelium interaction: from symptoms to ulceration. Angiology. 2005;56:S11-S19.

15. Badier-Commander C, Verbeuren T, Lebard C, Michel JB, Jacob MP. Increased TIM/MMP ratio in varicose veins: a possible explanation for extracellular matrix accumulation. J Pathol. 2000: 105-112.

16. Stvrtinova V, Jahnova E, Weissova S, Horvathova M, Ferencik M. Inflammatory mechanisms involving neutrophils in chronic venous insufficiency of lower limbs. Bratisl Lek Listy. 2001;102:235-9.

17. Bergan J, Molecular Mechanisms in Chronic Venous Insufficiency. Ann Vasc Surg. 2007;21:2606.

18. Coleridge Smith PD. Neutrophil activation and Mediators of inflammation in chronic venous insufficiency. J Vasc Res. 1999;36:24-36.

19. Takase S, Bergan JJ, Schmid-Schönbein G.W. Expression of adhesion molecules and cytokines on saphenous veins in chronic venous insufficiency. Ann Vasc Surg. 2000;14:427-435.

20. Dormandy JA. Influence of blood cells and blood flow on venous endothelium. Int. Angiol. 1996;15:119-23.

21. Gohel MS, Windhaber RAJ, Tarlton JFT, Whyman MR, Poskitt KR. The relationship between cytokine concentrations and wound healing in chronic venous ulceration. J Vasc Surg. 2008;48:1272-7.

22. Coleridge Smith PD. Update on chronic-venousinsufficiencyinduced inflammatory processes. Angiology. 2001;52: S35-S42.

23. Takase S, Delano FA, Lenrod L, Bergan JJ, SchmidSchonbein GW. Inflammation in chronic venous insufficiency: is the problem insurmountable? J Vasc Res. 1999;36:3-10.

24. Coleridge Smith PD, Thomas P, Scurr JH, Dormandy JA. Causes of venousulceration: a new hypothesis. Br Med J. 1988;296:1693-5.

25. Mangiafico RA, Malatino LS, Santonocito M, Spada RS, Benedetto FA. Plasma endothelin-1 release in normal and varicose saphenous veins. Angiology. 1997;48:769-74.

26. Boisseau MR. Leukocyte involvement in the signs and symptoms of chronic venous disease. Perspectives for therapy. Clin Hemorheol Microcirc. 2007;37:277-290.

27. Michiels C, Bouaziz N, Remacle J. Role of the endothelium and blood stasis in the appearance of varicose veins. Int Angiol. 2002;21:1-8.

28. Kirsch D, Dienes HP, Küchle R, Duschner H, Wahl $\mathrm{W}$, Böttger $\mathrm{T}$, Junginger $\mathrm{T}$. Changes in the extracellular matrix of the vein wall- the cause of primary varicosis? Vasa. 2000;29:173-7.

29. Saharay M, Shields DA, Porter JB, Scurr JH, Coleridge Smith D. Leukocyte activity in the microcirculation of the leg in patients with chronic venous disease. J Vasc Surg.1997;25:265-73.

30. Wali MA, Eid RA. Changes of elastic and collagen fibres in varicose veins. Int. Angiol. 2002;21:33743.

31. Khan AA, Eid RA, Hamid A. Structural changes in the tunica intima of varicose veins: a histopathological and ultrastructural study. Pathology. 2000;32:253-7.

32. Master K, Gacka M, Adamiec R. Usefulness of evaluation endothelial markers of immunoinflammatory activity In prognosis venous leg ulcer. Prz Flebol. 2005;13:3-7.

33. Coleridge Smith PD. Deleterious effects of white cells in the course of skin damage in CVI. Int Angiol. 2002;21:26-32.

34. Schmid Schonbein GW, Takase S, Bergan JJ. New advances in the understanding of the pathophysiology of chronic venous insufficiency. Angiology. 2001;52:S27-S34.

35. Takase S, Schmid Schönbein GW, Bergan JJ. Leukocyte activation in patients with venous insufficiency. J Vasc Surg. 1999;30:148-56.

Cite this article as: Vagholkar K, Garima $\mathrm{S}$, Kripalani Y. The role of inflammatory reaction in chronic venous disease of the lower limb. Int Surg J 2019;6:1835-7. 